\title{
Analysis of Translation Techniques in Thesis Abstracts of English and Indonesian Language and Literature Undergraduate Students
}

\author{
Zalinda Firdausyiah, Budi Hermawan*, Dian Dia-an Muniroh
}

\author{
Department Pendidikan Bahasa Inggris, Universitas Pendidikan Indonesia \\ *Corresponding author. Email: budihermawan@upi.edu
}

\begin{abstract}
Writing a quality abstract is important because abstract is a factor that determine whether a paper is worth to read or not. For researchers or students whose first language is not English, translation techniques must be taken into consideration as well, especially if they aim for international publication. Various studies related to translation techniques have been done previously, but not many analysed abstracts, especially from undergraduate students' theses that were written in two languages. Therefore, this study aims to analyse translation strategies of abstracts from English Language and Literature and Indonesian Language and Literature students of Universitas Pendidikan Indonesia. A total of 30 English and Indonesian abstracts along with the translations were taken from UPI's online repository to be analysed using Molina and Albir's (2002) translation techniques. From the analysis, it is shown that the translation technique that was used the most in abstracts from both study programs was Literal Translation, followed by Borrowing. However, 11 translation techniques are identified in abstract written by English Literature students, while only nine are identified from Indonesian Literature students' abstracts. The findings show that despite writing in different languages, students from both study program used similar translation techniques to translate their abstracts.
\end{abstract}

\section{Keywords: Abstracts, English, Indonesian, translation techniques}

\section{INTRODUCTION}

Translation can simply be understood as the process of transferring a text from a source language to a target language. Bassnett (2014) stated that nowadays, translating is a common human condition, and the rapid increase of media causes a rise in the importance of translation. In academic context, translation is a crucial part of knowledge transfer. If a research paper is not translated properly, the process of knowledge transferring may be disrupted. A research paper that is not written in English must be translated into English if the writer wishes it to get published in international journals. In a similar context, college students in Indonesia who are in their final year are also be required to write their thesis research abstracts in their research abstract in English in addition to their Indonesian abstract. An abstract itself is one of the most crucial parts of a research paper, as it represents the content of a research in a more condensed way (Cross \& Oppenheim, 2006; Koultay, 2010). An abstract should help readers gain a preview of information in a quick and comprehensive way (Kurniawan, Lubis, Suherdi, \& Danuwijaya, 2019). Not only that, an abstract also acts as an outline to help the readers understand its full content. Thus, abstracts that are translated with poor translation may hinder it from being discovered and read by many people, as well as getting published in international publication.

In relation to translation, translation techniques have been proposed by researchers in this field. Molina and Albir (2002) proposed 18 classifications of translation techniques, which will be used as the framework of this study. The techniques are adaptation, amplification, borrowing, calque, compensation, description, discursive creation, established equivalent, generalization, linguistic amplification, linguistic compression, literal translation, modulation, particularization, reduction, substitution, transposition, and variation. These translation techniques were derived from existing techniques of translations proposed by other experts such as Nida's (1964) translation theory and Newmark's (1988) translation methods. The translation techniques 
were developed because the methods, strategies, and techniques need to be further distinguished and the due to the need of functional concept of translation techniques (Molina \& Albir, 2002).

Several studies have been conducted with Molina and Albir's translation techniques to analyse the data. Anwar, Haryanti, and Mukti (2020) analysed the translation of Aladdin's movie script using the techniques. The findings of their study showed that linguistic compression was used the most prominently at $56.52 \%$, while other techniques occurred less frequently (10\% and below) Another research was conducted to investigate the translation of cultural words in The Da Vinci Code novel from English to Indonesian (Kuswahono, 2019). This study revealed that pure borrowing occurs the most (118 occurrences), followed by transposition (23 occurrences), while the rest occurred 10 or less times. Both studies show that there is a huge gap between the use of a translation technique that was used the most and the rest of the techniques.

Not only literature texts, but the translation techniques have also been used for example to analyse religious texts a well. Sodiq, Budiman, and Hidayat (2020) conducted a research to analyse religious tourism brochure in Indonesia. In their study, they revealed that translation techniques that were used the most in translating the Indonesian brochure to English is pure borrowing $(41 \%)$. There are a few others that appeared significantly less, but still above $10 \%$, while the rest occurred below 10\%. Another religious text that was analysed using the technique is Quranic metaphor or kinayah (Al Farisi, 2020). The result showed that the application of literal translation presented the primary meaning of the kinayah verses accurately while amplification presents the secondary meaning transparently with target language as the orientation.

As seen from the previous studies, it can be said that Molina and Albir's (2002) translation techniques have been used to analyse different types of texts. Anwar et. al (2020) and Kuswahono (2019) used the technique to analyse literature texts, while Sodiq et. al (2020) and Al Farisi (2020) employed the technique to analyse religious texts. However, translation techniques used in academic paper, specifically undergraduate students' thesis, are not often explored. Thus, this research aims to identify the translation strategies that are typically used by undergraduate students of English Language and Literature and Indonesian Language and Literature study program in writing their abstracts.

\section{METHOD}

\subsection{Research design}

This study is a qualitative study that analyses undergraduate students' abstracts that employed Molina and Albir's (2002) translation techniques to analyse the data. This study intended to identify translation techniques that undergraduate students from different study programs in writing their abstracts.

\subsection{Data sources}

The data consists of a corpus of 30 thesis abstracts. The abstracts were extracted from the theses of undergraduate English Language and Literature and Indonesian Language and Literature students. The abstracts that were taken must be written in two languages, English and Indonesian. However, due to the limited availability of the abstracts in Universitas Pendidikan Indonesia's online repository, the year of the abstracts' publication was not considered.

\subsection{Data collection}

First, the researcher accessed Universitas Pendidikan Indonesia's online repository. Second, the theses abstracts were checked starting from the most recently published. If it was written in English and Indonesian, the abstracts were downloaded. Third, the abstracts that were downloaded in PDF format were converted into docx format. The title, author name, and year of publication were written on top of the abstract.

\subsection{Data analysis}

Molina and Albir's (2002) translation techniques were employed as the main framework of this study and to analyse the abstracts' translation techniques. The techniques proposed by Molina and Albir were used because each technique was distinguished more clearly, and there is a functional dynamic in the techniques. The abstracts were broken down into sentences as the units of analysis. The text written in the source language and target language were put next to each other in order to ease the analysis process. Then, the translation techniques of each sentence were identified. Next, the translation techniques were counted by using tally marks to find out how many times the translation techniques occurred. Finally, the result of translation technique analysis between abstracts written by English Language and Literature Students were compared to Indonesian Language and Literature students.

\section{FINDINGS AND DISCUSSION}

This sub-section aims to look into the translation techniques further. The analysis result showed that the abstracts written by students from both English Language and Literature and Indonesian Language and Literature study program employed Literal Translation as the most dominant translation technique (106 and 138 times respectively). Table 1 shows the occurrence of each translation technique. 
Table 1. Salience of translation techniques in the research abstracts (RAs).

\begin{tabular}{ccc}
\hline $\begin{array}{c}\text { Translation } \\
\text { technique }\end{array}$ & $\begin{array}{c}\text { English Language } \\
\text { and Literature }\end{array}$ & $\begin{array}{c}\text { Indonesian } \\
\text { Language and } \\
\text { Literature }\end{array}$ \\
\cline { 2 - 3 } & $f(\%), \mathrm{n}=15$ & $f(\%), \mathrm{n}=15$ \\
\hline Adaptation & 7 & 7 \\
Amplification & 20 & 0 \\
Borrowing & 73 & 67 \\
Calque & 73 & 7 \\
Compensation & 40 & 7 \\
Discursive creation & 0 & 7 \\
Established & 20 & 13 \\
equivalent & & 0 \\
Generalization & 20 & 100 \\
Literal translation & 100 & 13 \\
Modulation & 13 & 13 \\
Reduction & 27 & 13 \\
Transposition & 27 & \\
\hline
\end{tabular}

\subsection{Adaptation}

This translation technique occurred $7 \%$ in abstracts written by both English Literature and Indonesian Literature students. The adaptation technique replaces cultural element from a source language with its equivalent in the target language (Molina \& Albir, 2002). This technique was used to adapt a character's name in one of the abstracts.

Penelitian ini menggunakan analisis struktural dan sosiologi sastra dalam melihat ketamakan yang ada pada Rahwana.

This research uses structural analysis and sociology of literature in seeing the greed that exists in Ravana.

(RA 7, Indonesian Language and Literature)

However, there is an interesting finding from this abstract. To translate the first two sentences, the author used adaptation and put "Ravana" to translate "Rahwana". However, in the rest of the sentences, the name was not adapted into the westernized spelling of the name, and the Indonesian spelling "Rahwana" was kept instead. This is done by the author possibly to keep the originality of the title of the story that is analysed in the thesis, Banjaran Rahwana.

\subsection{Amplification}

This move was appeared in $20 \%$ of the English students' RA and was not found in any abstracts authored by Indonesian students at all. This translation technique translates a source text and adds information that is not written in the source text into the target text (Molina \& Albir, 2002). In the abstracts that employed amplification, this technique was used to put together two sentences in the source text, add more details about the data that was analysed, and explain the result of the study in more details.

This study also shows six ways in which cohesive devices contribute to how the story proceeds.

Penelitian ini juga mengungkapkan enam konstribusi perangkat kohesi terhadap jalan cerita, yaitu (1) melacak jejak partisipan, (2) mengindari repitisi dan redudansi teks, (3) mengontrol arah wacana, (4) menekankan suatu peristiwa, (5) mengurangi kemonotonan dalam penggunaan bahasa, dan (6) menambahkan informasi pada partisipan atau peristiwa.

(RA 13, English Language and Literature)

\subsection{Borrowing}

Borrowing was found in the translations of both Indonesian and English students' RAs. The technique occurred $73 \%$ in English students' RA and $67 \%$ in Indonesian students' RA. In theory, the borrowing technique uses a word or expression from a source language without any changes (pure borrowing) or changing the spelling to fit the spelling rules (Molina \& Albir, 2002). In RAs written by English students, the authors employed pure borrowing to to display theoretical framework, findings, and conclusion.

Findings show that Moana is constructed as female hero mainly by framing and two aspect of mise-en-scène, which are costume and staging or performance, and two methods of characterization, which are external actions and foil character.

Hasil temuan menunjukkan bahwa Moana dikonstruksi sebagai pahlawan wanita menggunakan teknik pengambilan gambar dan dua aspek teknik pengadeganan atau mise-enscène, yaitu kostum dan performa.

(RA 9, English Language and Literature)

In RAs written by Indonesian students, however, this technique is often used to adapt titles of works used as the data source. This is done to keep the originality of the title. The technique was also applied to Indonesian terms that do not have an English equivalent. This technique was also used to display institution and place. Similar to the English students, Indonesian students also employ pure borrowing to translate the abstracts.

Sumber datanya adalah Novel Elang Menoreh (Perjalanan Purwa Kala) Karya Wiwien Wintarto yang diterbitkan pada tahun 2018, 357 halaman.

The data source for this study was Wiwien Wintarto's Novel entitled Elang Menoreh (Perjalanan Purwa Kala), published in 2018, 357 pages.

(RA 2, Indonesian Language and Literature)

\subsection{Calque}

This technique was also employed by English and Indonesian students in translating their RAs. This technique occurred 73\% in abstracts authored by English 
students and only $7 \%$ in abstracts authored by Indonesian students. This technique translates a word or phrase literally, either lexically or structurally (Molina \& Albir, 2002). This technique is different to Literal translation that translates a text word for word. The English students and Indonesian students similarly employed this technique to translate a term or theoretical framework.

Salah satu tradisi lisan tersebut adalah salawek dulang.

One of the oral traditions is salawek tray.

(RA 14, Indonesian Language and Literature)

A huge occurrence gap of this translation technique seems quite noticeable. Presumably, this is because the technique was commonly used to translate a term or theoretical framework from a source text to a target text. The researcher assumed that in the Indonesian abstracts, the writers used the theories adapted from English books, so they did the calque translation process in writing their abstracts, not when they translate their abstract to English.

\subsection{Compensation}

Compensation occurred $40 \%$ in English students' abstracts and only $7 \%$ in the Indonesian students' abstracts. Similar to adaptation, the occurrence of this technique in RAs from the two study programs seem to have a noticeable gap as well. Compensation, according to Molina and Albir (2002), is a technique where an element of a source text is introduced in another place in the target text. From the analysis, it was found that the technique was applied to introduce a part of the text that went through the reduction technique.

Hal ini diperantarai untuk menghasilkan makna dan intensi tambahan.dan juga untuk menyesatkan peserta persidangan.

(RA 8, English Language and Literature)

Compensation was applied in translating the excerpt above because in the source text, that part was introduced in a different part of the text and was attached to another sentence.

\subsection{Discursive creation}

Discursive creation is a translation technique that is applied the least to translate the RAs, with only $7 \%$ occurrence in Indonesian students' abstracts and none in English students' abstracts. Discursive creation is a technique to translate using an out-of-context equivalent (Molina \& Albir, 2002). In an abstract authored by an Indonesian student, this method is used to translate a medical condition, which is deafness.
Dengan demikian, semakin berat tingkat ketunarunguan maka semakin sedikit leksikon atau kalimat yang diproduksi.

Thus, the heavier the level of yellowness the less lexicon or sentence is produced.

(RA 4, Indonesian Language and Literature)

\subsection{Established equivalent}

Established equivalent is a technique of translating that uses a term or expression that is recognized in the target language. This technique occurred 20\% in English students' RAs and $13 \%$ in Indonesian students' RAs. Some parts of abstracts written by English students were translated using technique to transfer an English term that has an equivalent in Indonesian, such as the word "novel". On the other hand, Indonesian students employed the technique to translate regional language, which can be seen below.

Penggunaan bahasa di wilayah perbatasan Subang menggunakan bahasa Sunda, sedangkan wilayah perbatasan Indramayu menggunakan bahasa Jawa.

The language used in the Subang border area uses Sundanese, while the Indramayu border area uses Javanese.

(RA 5, Indonesian Language and Literature)

\subsection{Generalization}

Generalization occurred $20 \%$ in English students' RAs and does not occur at all in Indonesian students' RA. Molina and Albir (2002) stated that generalization is the technique to translate a sentence or text with a more general or neutral term. This technique was used to simplify a detailed explanation.

Clay Jensen is also a round character who develops himself from being selfish to be a more sympathetic person.

Clay Jensen juga berubah menjadi orang yang lebih simpatik dalam berinteraksi dengan orang lain.

(RA 1, English Language and Literature)

\subsection{Literal translation}

Literal translation is a technique that is applied in translating almost every sentence in the abstracts. It occurred $100 \%$ in both English students' RAs and Indonesian students' RAs. Literal translation is a technique of translating a source text into the target text word-by-word. From the analysis, it can be seen that this technique may cause the abstract writer to disregard grammatical rules and thus, make a translation mistake in their abstract.

Sumber data penelitian diperoleh melalui studi kepustakaan dan obeservasi lapangan.

Sources of research data obtained through library research and field observation.

(RA 7, Indonesian Language and Literature) 


\subsection{Modulation}

This translation technique occurred $13 \%$ in both English students' RAs and Indonesian students' RAs. According to Molina and Albir (2002), this technique is used to change the point of view, focus, or meaning of a sentence. In the RAs, this technique is used to change the focus of a sentence.

Pidato merupakan alat bagi politisi untuk membagi gagasannya kepada publik.

Jokowi Speech is a tool for politicians to share their ideas with the public.

(RA 3, Indonesian Language and Literature)

\subsection{Reduction}

Reduction is a translation technique that suppresses information from a source text in its target text (Molina \& Albir, 2002). It occurred 27\% in English students' RAs and $13 \%$ in Indonesian students' RAs. This technique was used by English students to reduce information in a sentence, usually because the omitted information was moved into another place in the text. This was done to adapt to the structure of a target language's text. However, this can also change or omit the meaning from the source text if the omitted meaning is not written somewhere else in the text.

It indicates that female characters are more active since they are the main character.

Hal ini dikarenakan wanita adalah tokoh utamanya.

(RA 12, English Language and Literature)

Indonesian students also employed this technique to translate their abstracts with the same purpose, to adjust the text's structure. The meaning differs slightly, but from the analysis, all the omitted information was introduced again in the sentence that followed.

Dalam penelitian ini terdapat dua sumber data, yaitu data primer dan data sekunder.

Furthermore, there are two main data of this research.

(RA 10, Indonesian Language and Literature)

\subsection{Transposition}

Transposition occurred 27\% in English students' RAs and $13 \%$ in Indonesians students' RAs. Molina and Albir stated that transposition is a translation technique that changes the grammatical category of a text. An example would be changing an active sentence into passive sentence vice versa, which was occasionally done by students from both study programs in translating their abstracts. Similar to the aforementioned technique, this technique was usually employed to adjust to the target text's language structure.

It was also found that the defendant only violated the maxim of quality.
Penelitian ini juga menemukan bahwa terdakwa melakukan pelanggaran tipe violation pada maksim kualitas.

(RA 8, English Language and Literature)

The findings above demonstrate that various translation techniques were employed in order to translate their abstracts from one language to another. Literal translation was identified in all abstracts and almost all sentences in the abstracts, while many of the other translation techniques were used as an embedded translation technique. Borrowing is the second-highest translation technique that occurred, but it is notable that there was a wide gap of occurrence between literal translation and rest of the translation techniques, borrowing included. A prominent gap can also be seen in occurrence of some translation techniques in RAs from different study programs, such as calque (73\% to $7 \%$ ) and compensation (40\% to $7 \%$ ). Furthermore, the analysis also found that most of the sentences were translated with one technique, while a small number were translated with two and three translation techniques at most.

This differs to the result of previous research (Anwar et al., 2020; Kuswahono, 2019; Sodiq et al., 2020). Their research stated that the translation technique that occurred the most in the texts they analyzed were linguistic compression (Anwar et al., 2019) and pure borrowing (Kuswahono, 2019; Sodiq et al., 2020). However, Al Farisi's (2020) showed a similarity to this study. His research found that literal translation was used the most. There was no clear pattern in which type of text a specific translation technique appears the most because all previous studies analyzed different texts, so further research is worth to conduct.

\section{CONCLUSION}

This study has identified the translation techniques that were employed by students from two study programs, English Language and Literature and Indonesian Language and Literature, in order to translate their abstracts. The findings revealed that the techniques that were applied to translate the abstracts slightly differ between the two study programs. English Language and Literature students employed adaptation, amplification, borrowing, calque, compensation, established equivalent, generalization, literal translation, modulation, reduction, and transposition. On the other side, Indonesian language and language students translated their abstracts using the following translation techniques: adaptation, borrowing, calque, compensation, discursive creation, established equivalent, generalization, literal translation, modulation, reaction, and transposition. This study concludes that regardless of the language of the source text, literal translation is the technique that is used the 
most with the salience of $100 \%$. Amplification and generalization are only used in translating English Language and Literature abstract and discursive creation only occurred in Indonesian Language and Literature abstract. Therefore, this may imply that the authors of the abstracts are more comfortable in translating wordto-word. However, it should be taken into consideration that the results of this present work only represent abstracts written by English Language and Literature and Indonesian Language and Literature study program. Results may differ if further analysis of abstracts from different study programs or level of study is done.

The result of the present study is expected to contribute to the existing literature related to academic writing, specifically for undergraduate students' thesis abstracts. This study suggests for universities to guide students in writing and translating abstracts using different translation techniques to achieve a good abstract translation. Additionally, this study recommends for a more extensive study that involves more data from different study programs to be conducted in order to further enrich the existing knowledge related to translation techniques in academic field.

\section{ACKNOWLEDGMENTS}

This study was supported by a grant from the Research and Community Service Unit, Indonesia University of Education. The authors would like to express appreciation for all the support provided.

\section{REFERENCES}

Al Farisi, M. (2020). The Impact of using foreignization and domestication on the translation accuracy of the Quranic metaphor (Kinayah) verses. Humanities and Management Sciences - Scientific Journal of King Faisal University, 21(1). https://doi.org/10.37575/h/rel/1966

Anwar, F. Z., Haryanti, D., \& Mukti, V. C. (2020). Translation techniques of expressive utterances used in the movie script of Aladdin. Proceedings of the 1st International Conference on Language, Literature, and Arts Education (ICLLAE 2019). Paris, France: Atlantis Press. https://doi.org/10.2991/assehr.k.200804.060

Bassnett, S. (2014). Translation (The new critical idiom). New York: Routledge.

Cross, C., \& Oppenheim, C. (2006). A genre analysis of scientific abstracts. Journal of Documentation, 62(4), $428-446$ https://doi.org/10.1108/00220410610700953

Koltay, T. (2010). Abstracts and abstracting: A genre and set of skills for twenty-first century (1st ed.; R. Rikowski, ed.). Oxford: Chandos Publishing.
Kurniawan, E., Lubis, A. H., Suherdi, D., \& Danuwijaya, A. A. (2019). Rhetorical organization of applied linguistics abstracts: does scopus journal quartile matter? Gema Online Journal of Language $\quad$ Studies, 19(4), 184-202. https://doi.org/10.17576/gema-2019-1904-10

Kuswahono, D. (2020). The use of translation techniques in translating cultural words in the Da Vinci Code Novel from English into Bahasa Indonesia, Anaphora, 3(1), 38-46. https://doi.org/10.30996/anaphora.v3i1.3642

Molina, L., \& Albir, A. H. (2002). Translation techniques revisited: A dynamic and functionalist approach. Meta, 47(4), 498 https://doi.org/10.7202/008033ar

Newmark, P. (1988). A textbook of translation. London: Prentice Hall International.

Nida, E. A. (1964). Toward a science of translating: With special reference to principles and procedures involved in Bible translating. Brill Archive.

Sodiq, J., Budiman, T. C. S., \& Hidayat, N. (2020). Translation techniques in translating cultural issues in the Indonesian religious tourism brochure in Semarang city. International Journal of Research in Education, 1(1), 33-40. 